\title{
Innowacja instytucjonalna w warunkach transformacji otoczenia
}

\author{
Agnieszka Dziubińska*
}

\begin{abstract}
Rozwój działalności biznesowej w otoczeniu rynków wyłaniających się stanowi wyzwanie dla wielu przedsiębiorstw stosujacych tradycyjne strategie. Częściowo jest to spowodowane tzw. ograniczeniami instytucjonalnymi. W konsekwencji tego dopasowane do filozofii rynków dojrzatych modele biznesowe moga wymagać rekonfiguracji. Konieczna jest identyfikacja morfologii otoczenia, która może okazać się trudna dla przedsiębiorstw spoza danego rynku. Dodatkowym aspektem, który należy wziąć pod uwage jest fakt, że transformacja instytucjonalna powoduje, iż otoczenie jest bardzo zmienne, co pociaga za sobq konieczność ciagtej rewizji założeń dotyczacych konfiguracji źródet wyników firmy. Celem autorki jest określenie roli instytucji rynków wytaniajacych się $w$ replikacji lub innowacji modelu biznesu. W realizacji postawionego celu wykorzystane zostana wyniki wtasnych badań, zrealizowanych na podstawie metod jakościowych (case study). Uogólnione wnioski postuża. do sformutowania wytycznych $w$ radzeniu sobie przedsiębiorstw $w$ warunkach niepewności otoczenia.
\end{abstract}

Słowa kluczowe: przedsiębiorczość instytucjonalna, ograniczania instytucjonalne, rynki wyłaniające się.

Nadesłany: 14.09.16 | Zaakceptowany do druku: 20.10.16

\section{The institutional innovation in terms of transition of the environment}

The development of business activity in the emerging market environment poses a challenge for many enterprises applying traditional strategies. It is partly due to the so called institutional voids. As a result, business models adjusted to mature market philosophy may require reconfiguration. An essential condition is identification of environment morphology which may turn out to be difficult for enterprises from outside a particular market. An additional aspect which should be taken into consideration is the fact that institutional transformation makes the environment highly volatile, which entails the need for continuous review of assumptions regarding the configuration of sources of company's performance. The objective of this article is to determine the role of emerging market institutions in replication or innovation of a business model. For the purposes of realisation of the objective set the results of author's own studies conducted on the basis of qualitative methods (case study) will be used. Generalised conclusions will be used to formulate guidelines for enterprises explaining how to manage in the conditions of uncertain environment.

\footnotetext{
Agnieszka Dziubińska, dr - Katedra Zarządzania Przedsiębiorstwem, Wydział Zarządzania, Uniwersytet Ekonomiczny w Katowicach.

Adres do korespondencji: Katedra Zarządzania Przedsiębiorstwem, Wydział Zarządzania, Uniwersytet Ekonomiczny w Katowicach, ul. Bogucicka 14, 40-227 Katowice; e-mail: agnieszka.dziubinska@ue.katowice.pl.
} 
Keywords: institutional entrepreneurship, institutional voids, emerging markets.

Submitted: 14.09.16 | Accepted: 20.10.16

JEL: M19

\section{Wstęp}

Kontekst instytucjonalny pomaga zrozumieć wybory strategiczne w zakresie tworzenia modelu biznesu przedsiębiorstwa. Jak ujął to North: „Modele ekonomiczne (i polityczne) są specyficzne dla konkretnej konstelacji instytucjonalnych uwarunkowań, które różnią się radykalnie, zarówno w czasie, jak i pomiędzy sektorami różnych gospodarek (...) modele te są specyficzne w zależności od instytucji (institutions-specific) i w wielu przypadkach wrażliwe na zróżnicowane instytucjonalne uwarunkowania" (North, 1990, s. 110). Pod pojecciem instytucji autor ten rozumial „reguły gry”, tj. jako „stworzone społecznie ograniczenia, które nadają strukturę społecznym interakcjom" (North, 1990, s. 3). Instytucje tworzą formalne reguły (np. prawo, regulacje, statuty) oraz nieformalne ograniczenia (zwyczaje, normy, przyjęte sposoby zachowania) (North, 1990, s. 36, 46).

Ujęcie to jest zgodne $\mathrm{z}$ koncepcją tzw. filarów otoczenia (Scott, 2001). Na fundamentalnym poziomie analizy instytucje tworzoną trzy „filary”: normatywny, regulatywny i kognitywny. Regulatywny to instytucje, takie jak reguły i przepisy prawa, które istnieją dla zapewnienia ładu i stabilności w społeczeństwie (North, 1990; Williamson, 1975, 1991). Przedsiębiorstwa zobowiązane są działać w zgodzie z literą prawa, co nie oznacza, że, szczególnie w dłuższym okresie, pozbawione są wpływu na te reguły (np. poprzez lobbing). Kognitywny filar nawiązuje do obszaru przynależnego psychologii społecznej (Berger i Luckmann, 1967; Kostowa i Zaheer, 1999) i kognitywnemu nurtowi teorii instytucjonalnej (Meyer i Rowan, 1977). Odnosi się on do poznawczych struktur społecznych, branych za pewnik przekonań, które są przyjmowane i wykorzystywane przez aktorów społecznych (Di Maggio i Powell, 1983). Filar normatywny (wychodzi poza formalne normy czy wiedzę) związany jest z legitymizacją. Kryjące się tu społeczne normy, wartości, przekonania wyznaczaja granice dla działań postrzeganych jako pożądane i właściwe
(Zimmerman i Zeitz, 2002). Jest to „stopień kulturowego wsparcia dla organizacji”, determinowany zgodnością wartości reprezentowanych przez organizacje i otoczenie (Meyer i Scott, 1983, s. 201). Domeny kognitywna i regulatywna wyłaniają się głównie w procesach edukacji i socjalizacji, natomiast normatywna w drodze politycznych procesów społecznych. Filary te nie muszą być traktowane oddzielnie, wręcz przeciwnie. W długim okresie stabilizacji bardziej prawdopodobny jest stan komplementarnej zgodności między nimi. $\mathrm{Na}$ przykład wartości wpływają na kognitywną kategoryzację i, w dalszej perspektywie, na regulacje, a te ostatnie znów oddziaływają na wartości. Każda z tych domen różni się zakresem, w jakim jest sformalizowana i jawna. W odpowiedzi na tak rozumiana strukturę otoczenia organizacje decydują się na szereg strategicznych rozwiązań, które są przejawem ich ustępliwości, aktywnego przyłączenia się lub oporu.

Rolą instytucji jest ,redukcja niepewności poprzez ustanawianie stabilnych (lecz niekoniecznie efektywnych) struktur, w ludzkich interakcjach (...) instytucje oddziaływają na wyniki całej gospodarki, poprzez ich wpływ na koszty wymiany i produkcji" (North, 1990, s. 5, 6). Braki instytucji pośredniczących, na gruncie teorii ekonomii instytucjonalnej, określane są jako „ułomności” i interpretowane jako ograniczenia dla przejrzystości procesów zachodzących w otoczeniu ${ }^{1}$. Słabe zabezpieczenie transakcji, komunikacji, transparentności może bowiem stwarzać okazje dla oportunistycznych zachowań partnerów i podnosi niepewność (Khanna i Palepu, 1997).

Zdaniem Northa (2005) we współczesnej gospodarce niepewność narasta wraz ze wzrostem współzależności jej elementów, głównie w domenie instytucji nieformalnych. Powodem jest niewspółmierność lub/i nieprzejrzystość norm i wartości, które kształtują instytucje formalne, oraz które stwarzają pośrednie podstawy dla podejmowanych decyzji. Efekty rozwoju tego trendu North wiaże ze złożonością. Warunki te określa jako nieergotyczne otoczenie cią- 
głej zmiany, w którym prognozowanie na podstawie przeszłych wzorców zachowań nie jest możliwe. Przyjęcie tych założeń otwiera intrygujące pole badawcze.

Nieprzewidywalność rozwoju w złożonych systemach społecznych, przynajmniej w pewnym zakresie, wynika z ludzkiej twórczości. W obliczu doświadczanej niepewności ludzie zdolni są do rozwoju innowacyjnych, nowych instytucji, albo sposobów tworzenia wartości. Ta twórczość przekłada się na innowację instytucjonalną. „Nowe instytucje powstają, gdy (...) zorganizowani aktorzy, wyposażeni w wystarczające zasoby (przedsiębiorcy instytucjonalni), dostrzegają w nich szanse zrealizowania interesów, które są dla nich ważne" (DiMaggio, 1988, s. 14). By nadać twórczości pewną dynamikę i sprawdzić przydatność twórczych pomysłów, potrzebne jest przedsiębiorcze podejście (Dyduch, 2013), przedsiębiorcy instytucjonalni „tworzą nowe systemy znaczeń, które wiążą razem działanie odrębnych zestawów instytucji” (DiMaggio, 1988, s. 14). Pojawienie się twórczego i przedsiębiorczego podejścia jest prawdopodobne nawet $\mathrm{w}$ warunkach tradycyjnie postrzeganych jako niepewne (Knight, 1929). W obliczu nieergotycznej niepewności konieczne staje się praktycznie ciaggłe eksperymentowanie w tworzeniu i replikowaniu instytucji, które podtrzymują działania dodające wartość zarówno przez przedsiębiorstwo, jak i sieci współpracujących $\mathrm{z}$ nim podmiotów.

W wymiarze strategicznym tradycyjne modele przedsiębiorstw, budowane na doświadczeniach rynków dojrzałych, w dużej mierze pomijały znaczenie odmienności w strukturze i dynamice instytucji rynkowych. Współcześnie obserwowane tendencje narastającej liczby połączeń między obszarami gospodarki światowej, między którymi nie zachodziły wcześniej znaczące interakcje, jest jednym z czynników, dla których w literaturze przedmiotu pojawił się postulat potrzeby głębszego zrozumienia interakcji między instytucjami i organizacjami (Li i Peng, 2008). Celem niniejszego artykułu jest określenie, czy i w jaki sposób, w warunkach doświadczanej złożoności otoczenia, jego instytucje mogą być dla przedsiębiorstw ograniczające lub/i ułatwiające prowadzoną działalność biznesową.

$\mathrm{Za}$ empiryczny kontekst rozważań wybrano przedsiębiorstwa inwestujące na zagranicznych rynkach wyłaniających się. Jak ujął to Scott, ,jest trudnym, jeśli nie niemożliwym, rozpoznanie wpływu instytucji na społeczne struktury i zachowania, jeśli wszystkie nasze przypadki są osadzone w takich samych lub bardzo podobnych" (Scott, 2001, s. 146). Zjawisko rynków wyłaniających się zmusza do poświęcenia większej uwagi problemowi infrastruktury otoczenia wspierającej realizacje zamierzeń przedsiębiorstwa międzynarodowego. Cechą rynków wyłaniających się jest, z jednej strony, brak instytucji właściwych dla rynków dojrzałych, czyli tzw. ograniczenia instytucjonalne (institutional voids) (Khanna i Palepu, 2010; Khanna i Palepu, 1997; Khanna, Palepu i Sinha, 2005). Z drugiej strony konkurencyjność przedsiębiorstw pochodzących z ,peryferii” gospodarki światowej rośnie, co sugerować może, że ich otoczenie stwarza warunki do rozwoju interesujących strategicznych form organizacji.

\section{Strategie radzenia sobie w warunkach ograniczeń instytucjonalnych}

Istota przedsiębiorstwa międzynarodowego związana jest $\mathrm{z}$ podejmowaniem działań na rynkach poszczególnych krajów. Na podstawie możliwych do wykorzystania źródeł przewagi przedsiębiorstwa klasyfikują rynki lokalizacji jako strategiczne lub komparatywne. Korzyści skali, które tradycyjnie uznawane były za zasadniczy motyw ekspansji międzynarodowej, skłaniały przedsiębiorstwa do stosowania replikacji procesów podstawowych. Wejście na rynek nie było możliwe bez uprzednio zdefiniowanego modelu biznesowego $\mathrm{z}$ wyspecyfikowanymi produktami, a strategia replikacji pozwalała zachować spójność i stabilność wyników (Baden-Fuller i Winter, 2005; Winter i Szulanski, 2001). Czynniki skuteczności w tym przypadku to skracanie czasu wdrożenia istniejacych rutyn i standardów. $\mathrm{Z}$ tego powodu w pierwszej kolejności przedsiębiorstwa szukają komplementarnych instytucji rynku, zainteresowane są bowiem redukcją ryzyka związanego np. z wykorzystaniem specjalistycznych zasobów. Zadaniem jednostek organizacyjnych jest redukcja złożoności otoczenia, np. dzięki zatrudnianiu większej liczby menedżerów o odpowiednim doświadczeniu. Rosnące znaczenie zasobów wiedzy sprawiło, że jako dodatkowy atut korzyści skali zaczęto dostrzegać możliwość innowacji w zakresie działalności podstawowej. 
Współczesne tendencje sprawiają, że innowacje produktowe przestają być wystarczające (Prahalad, Krishnan i Donker, 2004). W strategiach, których celem jest eksploracja, kryterium skuteczności wiąze się bardziej z uczeniem się niż z szybkością wdrażania rutyn. Otoczenie lokalne postrzegane jest wtedy jako cenne źródło zasobów wiedzy. Przedsiębiorstwo skłonne jest do angażowania się $\mathrm{w}$ bezpośrednie relacje z lokalnymi graczami, zatrudniania doświadczonych lokalnych menedżerów, rozwoju długookresowych inicjatyw, opóźniania globalnej standaryzacji. Rozwój odpowiednich procesów organizacyjnych, dających elastyczność na bazie uczenia się, przynosi nowe możliwości radzenia sobie z wyzwaniami zarówno replikacji, jak $\mathrm{i}$ innowacji.

Modele strategii międzynarodowych, ugruntowane doświadczeniami przedsiębiorstw pochodzących z rynków dojrzałych, implicite zakładały komplementarność otoczenia instytucjonalnego względem zasobów organizacji. Instytucje sprzyjały powiększeniu rynku, gdyż nawet w bardziej złożonych transakcjach nieznani sobie wcześniej partnerzy mogli oczekiwać zabezpieczania zysków (Johnson, LaPorta, Lopez-de-Silanes i Shleifer, 2000). Formalne instytucje rynku ułatwiały więc wejście na nowe rynki, obniżały koszt i stymulowały bardziej złożone formy ekspansji ekonomicznej (Williamson, 1985). Adekwatnie w krajach, w których brakowało takiej infrastruktury organiczno inwestycje, a gdy decydowano się już na rozwój działalności, realizacja celów strategicznych wymagała niwelowania i kompensowania lokalnie występujących różnic. Zarządzanie ryzykiem politycznym czy zmiennością regulatorów było nawet identyfikowane jako kluczowa kompetencja przedsiębiorstwa (Caves, 1996; Goldstein 2007, s. 99-102; Lall, 1983; Lecraw, 1993; 1977). Uwaga zarządzających koncentrowała się na definiowaniu otoczenia przez pryzmat formalnych instytucji i konfiguracji adekwatnych zasobów przedsiębiorstwa. Luki interpretowano jako czynniki dystansu podnoszące koszt działalności.

Ograniczenia instytucjonalne są jednym z kryteriów zaliczania rynków do grupy wyłaniających się. Za wyłaniający uznaje się rynek, na którym zaawansowane instytucje wspierające transakcje między kupującym i sprzedającym na rynkach zbytu, zatrudnienia czy kapitałowych nie występują lub funkcjonują w sposób nieefektywny. Na tej podstawie rynki wyłaniające się należy umieścić na kontinuum pomiędzy rynkami rozwiniętymi a tymi całkowicie dysfunkcyjnymi (Khanna i Palepu, 2010, s. 24-25). Jako główne źródła ograniczeń instytucjonalnych Khana i Palepu wymieniaja brak źródeł albo nierzetelne źródła informacji o rynkach, niepewność $\mathrm{w}$ sferze regulacji, niewydajny system prawny (Khanna i Palepu, 2010, s. 16). Rynki wyłaniające się, w porównaniu do rynków dojrzałych, tradycyjnie postrzegane były jako te, które znajdują się na niższym poziomie rozwoju, stąd w strategiach przedsiębiorstw nie były klasyfikowane jako źródła przewagi wynikających z innowacji (Yip, 1996). Transformacja sprawia jednak, że otoczenie staje się wysoce dynamiczne (Peng i Luo, 2000), co nie ułatwia replikacji skomplikowanych modelów biznesowych, wymagających komplementarnych instytucji.

Tradycyjne założenia na temat możliwości rozwoju na rynkach wyłaniających się mogą nie przynosić spodziewanych rezultatów (Khanna i Palepu, 2006, 1997; Prahalad i Lieberthal, 2003). Odmienne uwarunkowania mogą bowiem wymagać odmiennych rozwiązań organizacyjnych i strategicznych (Mathews, 2006). Przedsiębiorstwa, które podejmowały to wyzwanie, próbowały sobie radzić z niepewnością, wzmacniając jasno granice firmy, chroniąc zasoby i kompetencje przed niezamierzonym wyciekiem, szukając partnerów biznesowych władających mocnymi kompetencjami, rekompensującymi luki $\mathrm{w}$ infrastrukturze otoczenia biznesowego (Dunning, 1988). Strategie takie miały pozwolić na przeczekanie czasu potrzebnego, aby rynki te osiągnęły poziom rozwoju zbliżający je do modelu rynków dojrzałych. Inaczej mówiąc: do czasu, gdy formalne kontrakty zdominują stosunki społeczne, a przewaga konkurencyjna ugruntowana będzie w zdolności ochrony zasobów i wiedzy, przed niechcianymi powiązaniami zewnętrznymi.

Złożony charakter systemu zarówno gospodarki światowej, jak i samych rynków wyłaniających się, może powodować odmienną ścieżkę ich rozwoju. Należy podkreślić, że doświadczenia ostatnich lat pokazują, iż nawet rynki tradycyjnie uważane za dojrzałe, czasowo nabieraja cech rynków wyłaniających się. W takich okolicznościach rozwinięta w przedsiębiorstwie zdolność do twórczego radzenia sobie $\mathrm{z}$ nowymi insty- 
tucjami może mieć wartość strategiczną. Jak twierdzi Olivier, przedsiębiorstwa nie są bowiem skazane na pasywne dopasowywanie do otoczenia instytucjonalnego, lecz moga je zmieniać poprzez rozwijanie strategicznych inicjatyw (Oliver, 1991). Instytucjonalna innowacja może oznaczać powstanie całkiem nowej instytucji. Za innowację instytucjonalną można też uznać zmianę $\mathrm{w}$ istniejących instytucjach jako rezultat adaptacji dla wykorzystania dostrzeżonych szans, zmiany otoczenia albo jako uwrażliwienia na nowe warunki kulturowe (Raffaelli, Glynn, 2013). Jak ujmują to Hardgrave i Van de Ven (2006, s. 866), innowacją jest „twórczy proces działań grupowych, w których instytucje są kreowane". Za innowację uznać można również „instytucjonalną zmianę rozumianą jako różnica w formie, jakości albo w stanie instytucji w czasie" (Hardgrave i Van de Ven, 2006, s. 866). Aby innowacja miała strategiczny charakter przedsiębiorstwa, powinna wiązać się z głęboka konceptualizacja zmiana w modelu biznesu, przekształcić istniejący rynek, powodować zasadniczą poprawę w wartości dostarczanej klientom (Heiko i in., 2012, Christensen i in., 2002, Pitt i Clarke, 1999). Sukces takich inicjatyw wymaga jednak dostępu do specyficznych, lokalnych zasobów (Meyer, 2004). Menedżerowie rozwijają kompetencje radzenia sobie w konkretnym otoczeniu instytucjonalnym, kumulując zdobywane w określonym czasie doświadczenie (learning by doing) (Eirksson, Johanson, Majkgård i Sharma, 1997; Johnson i Vahlne, 1977). Tą drogą tworzą się pewne założenia, poglądy, które determinują sposób, w jaki kształtują oni swoje relacje $\mathrm{z}$ otoczeniem zewnętrznym. Teza ta otwiera pole do poszukiwań sposobów neutralizujących ograniczenia rynku.

\section{Metodyka badań empirycznych}

Prezentowane w artykule wyniki stanowią element szerszych badań prowadzonych $\mathrm{w}$ zakresie strategii przedsiębiorstw międzynarodowych na rynkach wyłaniających się. W przygotowaniu projektu badawczego przyjęto podejście jakościowe $\mathrm{z}$ wykorzystaniem case study (Dul i Hak, 2008, Dul, Hak, Goertz i Voss, 2010). Uzasadnieniem dla wyboru tej metody były przyjęte założenia, że przejrzyste granice między procesem, treścią i kontekstem strategii są trudne do wyznaczenia (De Witt i Meyer, 2005), natomiast wymiary te mają istotne znaczenie dla powstających wzorców (Yin, 1981). Procedurę badawczą zaprojektowano na podstawie metodyki zaproponowanej przez Dul i Hak w zakresie budowy teorii, dotyczacej relacji między znanymi konceptami (Dul i Hak, 2008, s. 177 i nast.). Podejście to czerpie $\mathrm{z}$ wcześniejszych metodologii case study (Eisenhardt i Graebner, 2007; Strauss i Corbin, 1998; Yin, 1981). Prezentowane wyniki powstały w związku z poszukiwaniem wzorców w relacjach zachodzących w kontekście organizacyjnym jednostki organizacyjnej (FDI) i kontekście otoczenia zewnętrznego (rynku lokalizacji FDI). Jednym z zadań, jakie przyświecało projektowaniu procedury i modelu badawczego, było uwzględnienie złożoności i heterogeniczności właściwej dla przedsiębiorstw międzynarodowych (Ghoshal i Noria, 1997, s. 12). Uwzględniono fakt, że granice konkretnej jednostki organizacyjnej mogą być możliwe do uchwycenia jedynie w wymiarze empirycznym, gdyż sa wynikiem nachodzenia na siebie dwóch zakresów organizacyjnych: wewnętrznych i zewnętrznych. Zakresy te tworzone są przez nakładające się różne rodzaje relacji: administracyjnych, bezpośrednich oraz pośrednich (Forsgren, Holm i Johanson, 2005). Pod uwagę wzięto także, że procesy strategiczne przebiegają w warstwie społecznej i (przynajmniej w pewnej części) procesy te przyjmuja niejawną postać, przez co są trudne w obserwacji. Dotyczy to szczególnie ujętych w rozważaniach procesów kognitywnych i normatywnych.

Celem przeprowadzonego badania nie była generalizacja ani formułowanie uogólnień na całą populację, lecz odkrycie czynników w przebadanych przypadkach, które wpływają na konfigurację działań w warunkach złożonego otoczenia. Tak sformułowane zadanie stanowiło uzasadnienie dla eksploracyjnego studium przypadku i celowego doboru przedsiębiorstw do analizy. Charakterystykę przypadków w próbie badawczej zawiera tabela 1.

Dane pozyskiwano z kilu źródeł dla zapewnienia trafności i wiarygodności wyników badania. W zakresie badań w terenie gromadzono materiał empiryczny, przy wykorzystaniu wywiadu bezpośredniego strukturalizowanego i wywiadu bezpośredniego niestrukturalizowanego. Przeciętny czas trwania wywiadu to 1,5 godz.; w sumie przeprowadzono 52 wywiady, według przygotowanego wcześniej scenariusza. W trak- 
Tabela 1. Podstawowa charakterystyka firm w próbie badawczej

\begin{tabular}{|l|l|c|c|l|l|}
\hline Firma & $\begin{array}{c}\text { Kraj } \\
\text { pocho- } \\
\text { dzenia }\end{array}$ & $\begin{array}{c}\text { Wielkość } \\
\text { obrotu } \\
\text { (ZIB/firma; } \\
\text { w mln EUR) }\end{array}$ & $\begin{array}{c}\text { Liczba } \\
\text { zatrudnionych } \\
\text { (ZIB/cała firma) }\end{array}$ & $\begin{array}{c}\text { Lokalizacja } \\
\text { wybranej ZIB } \\
\text { (czas wejścia) }\end{array}$ & $\begin{array}{c}\text { Forma } \\
\text { organizacyjna } \\
\text { ZIB }\end{array}$ \\
\hline Firma I & Polska & $3 / 7$ & $50 / 90$ & Kolumbia (2007/2012) & Własny odział/JV \\
\hline Firma II & Niemcy & $23 / 45$ & $50 / 300$ & Chiny (2003/2008) & JV/Własny odział \\
\hline Firma III & Włochy & $128 / 323$ & $600 / 2800$ & Malezja (1988) & Własny odział \\
\hline Firma IV & Polska & $4 / 70$ & $23 / 120$ & Rosja (2007-2009) & JV \\
\hline Firma V & Niemcy & $11 / 63$ & $25 / 160$ & Chiny (2008) & JV \\
\hline
\end{tabular}

Źródło: opracowanie własne.

cie trwania całej procedury badawczej zapewniony był stały kontakt z przedstawicielami badanych firm; ponadto odbyło się wiele dodatkowych spotkań (np. podczas targów branżowych organizowanych w różnych krajach, wizyt w przedsiębiorstwach w celach niezwiązanych bezpośrednio $\mathrm{z}$ badaniem). Pozyskane tą drogą informacje również były cennym źródłem, pozwalającym lepiej zrozumieć zjawiska zachodzące w organizacjach. Podmiotami badawczymi były dobrane celowo przedsiębiorstwa działające w skali międzynarodowej i oddziały zagraniczne tych firm zlokalizowane na rynkach wyłaniających się. Badania prowadzono w dwóch etapach (okres zbierania danych w terenie to luty 2009-grudzień 2012, badania wstępne: listopad 2005-styczeń 2006). Przestrzenny zakres prowadzonych badań to Polska, Kolumbia, Chiny, Malezja, Rosja, tj. rynki wyłaniające się, w których znajdowały się FDI przedsiębiorstw międzynarodowych. W próbie znalazły się przedsiębiorstwa pochodzące zarówno z rynków dojrzałych, jak i wyłaniających się, tj. z Niemiec i Włoch, oraz Polski. Analizy dokonywano, porównując przypadki parami w różnych przekrojach, tj. wg.: kraju pochodzenia i kraju inwestycji, wielkości, branży, formy FDI oraz rezultatu strategicznego (sukces-porażka).

Założenia badawcze miały na celu zapewnienie szczegółowego wglądu w historycznie przebiegające procesy wraz $\mathrm{z}$ ich kontekstem. Przy ustalaniu wielkości próby uwzględniono też ograniczenia związane z koniecznością przetwarzania dużej ilości danych. Dobór zapewnić miał również jak najlepszy dostęp do danych. W próbie znalazło się pięć podmiotów, którymi były centrale i oddziały zagraniczne małych i średnich przedsiębiorstw międzynarodowych, działających w jednej branży - producentów maszyn górniczych i ich elementów. Wywiady zostały przeprowadzone wśród prezesów firm, prezesów oddziałów, pracowników mających istotną wiedzę na temat procesu strategii.

\section{Opis przypadków - replikacja i innowacja modelu biznesu}

W próbie badawczej znalazł się jeden przypadek stanowiacy przykład przedsiebiorstwa odpowiadający określanemu wyżej jako tradycyjny. W realizacji zamierzeń strategicznych Firma III w dużym stopniu korzystała $\mathrm{z}$ infrastruktury rynku odpowiadającej modelowi zachodniemu, a braki w tym zakresie identyfikowano jako przeszkody. Przykładowo, w obliczu braku odpowiedniej jakości dostawców, do inwestycji i współpracy za granicą, zapraszano dotychczasowych kooperantów. Firma negocjowała warunki inwestycji z władzami lokalnymi. Realizację planów ułatwiała silna pozycja na rynku międzynarodowym. Firma III zalicza się do czołówki producentów w zakresie oferowanego przez siebie asortymentu.

Firmy II oraz V (podobnie jak Firma III) dokonywały replikacji swoich modeli biznesu (tzn. przenosity rozwiązania wypracowane na innych rynkach). W odróżnieniu od Firmy III przypadki te nie dysponowały dużymi zasobami, ani dominującą pozycją w branży światowej. Firma II oraz V nie mogły więc stosować oporu w obliczu ograniczeń otoczenia, a raczej sięgać musiały po inne swoje atuty. Firma II posiadała silne techniczne kluczowe kompetencje, które 
rozwijała w wymagajacym otoczeniu innowacyjnych firm w okolicach Monachium (również branży samochodowej). Wiedza ta została „wbudowana w tkankę organizacji”. Realizujac procesy podstawowe na rynkach zagranicznych (głównie Chin i Rosji), firma „wyprzedzała” lokalne standardy, jednak, jak podkreślał wielokrotnie sam Prezes Firmy II, zaawansowane produkty wymagały komplementarnej infrastruktury: technologicznej i społecznej. Ewentualne braki w tym zakresie identyfikowane były jako powody zmuszające do adaptacji. Postrzegano ją jednak jako „wymuszony kompromis”, lub, jak określił to respondent, „krok w tył”. Z drugiej strony należy zaznaczyć, iż zaprojektowane rozwiązania nie zawsze odpowiadały oczekiwaniom i wymogom lokalnych warunków konkurencyjnych.

Firma II konkurencję traktowała jako naturalny element rozwoju. Do wspó1pracy $\mathrm{z}$ podmiotami zewnętrznymi firma ta skłonna była przystąpić w sytuacjach, w których nie posiadała atutów do prowadzenia gry konkurencyjnej, albo gdy współpraca była konieczna do osiagania celów. Firma II na rynku zagranicznym współpracę prowadziła m.in. z państwowymi jednostkami $\mathrm{B}+\mathrm{R}$, co ułatwiło wejście na rynek, oraz z uniwersytetami technicznymi w celu pozyskania kadry o odpowiednich kwalifikacjach. W ramach współpracy Firma II wykazywała sie niestandardowym i twórczym podejściem, co przynosiło korzyści zaangażowanym stronom. Był to czynnik, który wyróżniał Firmę II na tle konkurencji. Firma ta osiągnęła pozycję lidera na rynku zagranicznym.

Firma V, podobnie jak Firma II, zamierzała wykorzystać na rynku zagranicznym swoje dotychczasowe doświadczenia Firma V również posiadała silne kompetencje techniczne, ale nie była skłonna do dokonywania zmian w swoim modelu biznesu. Uzasadnieniem dla takiej strategii była obawa o pogorszenie dostarczanej dla klienta wartości. Firma V nie zrealizowała swoich celów strategicznych na rynku zagranicznym. Wybrana przez tą firmę strategia replikacji okazała się więc nieskuteczna.

Firmy I oraz IV to przypadki podmiotów, które wchodząc na rynek zagraniczny, wprowadzały innowacje modelu biznesu; obie zdecydowały się na podjęcie nowej dla siebie działalności. Firma I traktowała ograniczenia instytucjonalne jako cenne kierunkowskazy na ścieżce rozwoju. Jed- nym z priorytetów rozwoju działalności było przekonanie o konieczności budowania zaufania lokalnych partnerów, co przesądzało np. o wyborze formy FDI pod postacią własnego oddziału. Służyły temu również wizyty przedstawicieli inwestora w Firmie I, jakie miały miejsce przed ostateczną decyzją o współpracy. Potem również stosunkowo częste były wzajemne wizyty w związku z realizacją warunków kontraktu. Bezpośrednie kontakty ułatwiły dialog między partnerami, oraz pomogły w wyłonieniu kluczowych aktorów związanych z projektem.

Same zespoły projektowe składały się z przedstawicieli obu partnerów. Bardzo ważna była też architektura zespołów wykonawczych, gdyż na rynku zagranicznym brak wykwalifikowanych pracowników był jedną z najważniejszych barier rozwoju w branży. Mieszany skład zespołów był pomysłem Firmy I i miał na celu przeszkolenie załogi inwestora, która zapewni ciągłość prac po zakończeniu kontraktu. Rozwiazanie takie niosło ze sobą ryzyko redukcji dochodów Firmy I (nawet do $40 \%$ ), ale był to ważny sygnał dla inwestora o wzajemnym zaufaniu. Całą załogę zakwaterowano wspólnie w kampusie, którego standard podniesiono do poziomu warunków europejskich. Komunikacja między pracownikami odbywała się w języku hiszpańskim. Wszystkie te zabiegi sprzyjały budowaniu atmosfery głębokiego dialogu i były warunkiem wstępnym do rzeczywistego zaangażowania stron projektu. W obliczu braku możliwości dochodzenia roszczeń na drodze prawnej sama umowa została skonstruowana tak, by obaj partnerzy byli współzależni w osiaganych wynikach (wspólny sukces lub wspólna porażka).

Natura więzi łącząca partnerów pomagała też efektywnie rozwiązywać przeszkody pojawiające się w trakcie trwajaccych prac. W czasie współpracy podjęto kilka nieplanowanych zmian w zakresie stosowanych rozwiązań (dotyczących np. stosowanego sprzętu czy technologii, ale też sposobów finansowania). Partnerzy ponosili wspólnie ryzyko i koszty eksperymentów. W późniejszym okresie rozwiązania te zyskały zainteresowanie innych klientów, a zdobyte doświadczenia stanowiło mocną stronę firmy.

Warto podkreślić, iż realizowane projekty były jednymi z najbardziej zaawansowanych technologicznie na rynku zagranicznym. Stąd były często wizytowane przez 
przedstawicieli innych kopalń, a także struktur administracji państwowej. Okazało się to skutecznym sposobem promocji, tym bardziej, że na rynku brakowało tradycyjnej infrastruktury informacyjnej. Z powodu uwarunkowań kulturowych na wybranym rynku zagranicznym bardzo istotna okazała się społeczna legitymizacja prowadzonej tam działalności. Firma I od początku deklarowała swoją chęć zaangażowania w procesy edukacyjne, podnoszące zakres wiedzy na temat współczesnych metod eksploatacji złóż węgla kamiennego. Odział Firmy I sta się (jako pierwszy z inwestorów zagranicznych) uczestnikiem rządowego programu SENA $^{2}$. Projekt miał charakter non profit, ale udział $\mathrm{w}$ nim podniósł prestiz firmy i otworzył drogę do zdobywania kolejnych relacji. Firma I została zaproszona, w roli eksperta, do konsultacji w zakresie tworzenia nowych przepisów regulujących bezpieczeństwo w kopalniach węgla kamiennego.

W trakcie rozwoju działalności na rynku zagranicznym Firma I zmieniła swoją wizję. Pod wpływem nowych wyzwań rozbudowała swój zespół, dokonując reorientacji kompetencji z handlowo-usługowych, w kierunku inżyniersko-projektowych. Swoją wizję pro- jektu zmienił również sam inwestor. Sprzyjał temu program odbytych delegacji, gdyż obejmował prezentację całych systemów wydobycia (nie tylko poszczególnych produktów). Firma I osiagnęła znaczaca pozycję konkurencyjną na rynku zagranicznym i została jednym $z$ największych inwestorów pochodzących z Polski.

Firma IV na rynek zagraniczny weszła z zamiarem aplikacji jednego ze swoich produktów, ale w nowej dla siebie branży. Ze względu na brak znajomości rynku zawiązano JV z partnerem lokalnym, który miał odpowiadać za organizację działań na miejscu. Okazało się jednak, że zakres i charakter zmian, które rekomendował partner, był zbyt duży dla Firmy IV. Firma ta ostatecznie wycofała się $\mathrm{z}$ rynku; w świetle przyjętych założeń została więc uznana za nieskuteczny przykład innowacji w modelu biznesu.

Przykłady ilustrujące oryginalne radzenie sobie $\mathrm{z}$ ograniczeniami otoczenia, zidentyfikowane $\mathrm{w}$ przypadkach przedsiębiorstw uznanych za sukces strategiczny, zawiera tabela 2. Dane przyporządkowano filarom otoczenia: regulatywnym, kognitywnym i normatywnym.

Tabela 2. Innowacja i replikacja modelu biznesu - przypadki sukcesu strategicznego

\begin{tabular}{|c|c|c|}
\hline $\begin{array}{c}\text { Firma I } \\
\text { (innowacja modelu biznesu) }\end{array}$ & Instytucje & $\begin{array}{c}\text { Firma II } \\
\text { (replikacja modelu biznesu) }\end{array}$ \\
\hline $\begin{array}{l}\text { - Niski standard prawa górniczego jako } \\
\text { pole do współpracy z partnerami bizne- } \\
\text { sowymi, organizacjami branżowymi oraz } \\
\text { przedstawicieli administracji państwowej } \\
\text { - Uczestnictwo w konsultacjach dot. two- } \\
\text { rzenia prawa górniczego } \\
\text { - Obsługa bieżącej działalności gospodar- } \\
\text { czej, w jak największym zakresie, prowa- } \\
\text { dzona wewnątrz firmy }\end{array}$ & Regulatywne & $\begin{array}{l}\text { - Stosowanie prawnej ochrony paten- } \\
\text { tów, ale łącznie z dodatkowymi roz- } \\
\text { wiązaniami technicznymi } \\
\text { - Przepisy prawa górniczego jako } \\
\text { element skłaniający do adaptacji } \\
\text { produktów } \\
\text { - Obsługa bieżącej operacyjnej dzia- } \\
\text { łalności w formie outsourcingu }\end{array}$ \\
\hline $\begin{array}{l}\text { - Brak wykwalifikowanej siły roboczej } \\
\text { był przyczyną utworzenia oryginalnych } \\
\text { zespołów roboczych } \\
\text { - Uczestnictwo w roli eksperta w rządo- } \\
\text { wym programie edukacyjnym } \\
\text { - Otwarte dzielenie się wiedzą z szerokim } \\
\text { gronem interesariuszy } \\
\text { - Utrwalanie stosowanych standardów } \\
\text { technicznych (np. przez wprowadzanie } \\
\text { nazw urządzeń i narzędzi, które nie funk- } \\
\text { cjonowały wcześniej w branży lokalnej) } \\
\text { - Szkolenia pracowników; równie ważna } \\
\text { jak wiedza techniczna była nauka języka } \\
\text { obcego }\end{array}$ & Kognitywne & $\begin{array}{l}\text { - „Kontrolowana” współpraca z pań- } \\
\text { stwowymi jednostkami B+R, oraz } \\
\text { współpraca z uniwersytetami tech- } \\
\text { nicznymi } \\
\text { - Staże dla studentów, które zwięk- } \\
\text { szają szanse na pozyskiwanie pra- } \\
\text { cowników o odpowiednich kwalifi- } \\
\text { kacjach technicznych } \\
\text { - Adaptacja własnych rozwiązań } \\
\text { technicznym do wymogów lokal- } \\
\text { nych (handlowych i technicznych) } \\
\text { - Zabezpieczanie własnych interesów } \\
\text { przez wprowadzane rozwiązania } \\
\text { techniczne }\end{array}$ \\
\hline
\end{tabular}

Wydział Zarządzania UW ～DOI 10.7172/1733-9758.2017.24.5 
Tabela $2 \mathrm{~cd}$.

\begin{tabular}{|c|c|c|}
\hline $\begin{array}{c}\text { Firma I } \\
\text { (innowacja modelu biznesu) }\end{array}$ & Instytucje & $\begin{array}{c}\text { Firma II } \\
\text { (replikacja modelu biznesu) }\end{array}$ \\
\hline $\begin{array}{l}\text { - W przypadku nieprzewidzianych trud- } \\
\text { ności projektowanie rozwiązań technicz- } \\
\text { nych z wykorzystaniem lokalnie dostęp- } \\
\text { nego sprzętu } \\
\text { - Próby obsadzania stanowisk na wyższych } \\
\text { szczeblach zarządzania przez lokalnych } \\
\text { menedżerów (co miało również konse- } \\
\text { kwencje należące do domeny normatyw- } \\
\text { nej) }\end{array}$ & Kognitywne & \\
\hline $\begin{array}{l}\text { - Wspólnota interesu jako zabezpieczenie } \\
\text { realizacji kontraktów } \\
\text { - Demonstracja zamiaru długoterminowe- } \\
\text { go zaangażowania na rynku } \\
\text { - Pozyskiwanie zaufania potencjalnych } \\
\text { klientów poprzez otwartą prezentację } \\
\text { realizowanych projektów } \\
\text { - Podnoszenie standardów socjalnych dla } \\
\text { pracowników z rynku lokalnego }\end{array}$ & Normatywne & $\begin{array}{l}\text { - Budowanie wizerunku firmy inno- } \\
\text { wacyjnej o wysokim standardzie, } \\
\text { jako odpowiedź na przekonanie } \\
\text { o dyskryminacji inwestorów zagra- } \\
\text { nicznych } \\
\text { - Wprowadzanie w wizerunek oddzia- } \\
\text { łu firmy elementów lokalnych } \\
\text { - Budowanie silnych relacji z klien- } \\
\text { tami } \\
\text { - Ograniczone lokowanie najważniej- } \\
\text { szych elementów działalności na } \\
\text { rynku zagranicznym z obawy przed } \\
\text { kopiowaniem }\end{array}$ \\
\hline
\end{tabular}

Podsumowując: w próbie badawczej znalazły się przedsiębiorstwa, które stanowia przykłady różnego podejścia do ograniczeń instytucjonalnych. Firma III stanowi przykład podejścia do barier rozwoju działalności na rynku wyłaniającym się, które zostało określone wyżej jako tradycyjne. Replikacja w takim przypadku polega na neutralizacji wpływu na organizację jak największej ilości instytucji, co wymagałoby zmiany sposobu działania. Uzasadnione wydaje się przekonanie, że strategia taka wymaga odpowiedniej siły rynkowej (Hymer, 1976). Podejście takie zawiodło w przypadku mniejszych niż Firma III, Firm IV oraz V. Jak pokazują przykłady Firm I oraz II, brak zakumulowanego kapitału może być rekompensowany przedsiębiorczym podejściem do instytucji Należy zauważyć, że chociaż oba przypadki uznano za sukces strategiczny, to firmy radziły sobie $\mathrm{z}$ odczuwalną złożonością otoczenia w odmienny sposób. Problem ten został szerzej omówiony w następnym punkcie.

\section{Wnioski i refleksje}

Uzyskane wyniki sugerują, iż możliwości implementacji inicjatyw czy całych modeli biznesowych w warunkach rynków wyłaniających się powinny być analizowane pod kątem morfologii instytucjonalnej rynku. W badaniach własnych uwzględniono podział instytucji na regulatywne, normatywne i kognitywne. Ewentualna analiza obejmować może więc przykładowo w zakresie filaru regulatywnego następujące kwestie: czy i w jakim stopniu potrzebna jest gwarancja prawna zawieranych umów, w jaki sposób można chronić własność intelektualną, jakie źródła kapitału będą potrzebne; w zakresie normatywnym: czy elementy modelu biznesowego zyskają legitymizację społeczną; w filarze kognitywnym: czy są odpowiednie zasoby ludzkie pod kątem wykształcenia, czy są szkoły czy jednostki badawcze itd., które umożliwią realizację zamierzeń na satysfakcjonującym poziomie. Wydaje się, że postrzegane braki i granice elastyczności w ich niwelowaniu zależą od eksploracyjnego lub eksploatacyjnego charakteru realizowanej działalności.

Przypadki przedsiębiorstw, które znalazły się w próbie badawczej, stanowią przykłady różnego podejścia do instytucji rynku wyłaniającego się. Nie bez znaczenia pozostaje fakt, iż każdy z filarów tego otoczenia różni się stopniem formalizacji i jawności, 
czyli możliwości bezpośredniego poznania, szczególnie dla podmiotów „z zewnątrz”. Podejście tradycyjne, które jest najszerzej opisane w literaturze przedmiotu, zostało rozwinięte na podstawie doświadczeń rynków dojrzałych. W tym przypadku, na nowych dla siebie rynkach zagranicznych, przedsiębiorstwa skłonne są przykładać największą wagę do domeny regulatywnej, którą charakteryzuje stosunkowo najwyższy poziom formalnej kodyfikacji. Niemniej pomijanie dwóch pozostałych domen w złożonym otoczeniu może prowadzić do utracenia szans, a w przypadku mniejszych przedsiębiorstw nawet do porażki strategicznej.

Ilustrację tradycyjnego podejścia stanowi przypadek Firmy III, która w prowadzonej działalności ograniczenia instytucjonalne rynku wyłaniającego się w całości uznawała za bariery. Firma ta w największym zakresie, wyznaczników w rozwoju działalności na rynku zagranicznym, poszukiwała w filarze regulatywnym. W ramach swoich możliwości w tym obszarze starała się także oddziaływać na otoczenie, wykorzystując przewage negocjacyjną. Pomysłem na wypełnianie ograniczen w filarze kognitywnym było przenoszenie wypracowanych relacji i rozwiązań z rynku macierzystego. Domena normatywna praktycznie nie stanowiła obszaru zainteresowania strategicznego.

W przypadkach bardziej twórczego podejścia do o graniczeń instytucjonalnych, uwagę poświęcano wszystkim filarom otoczenia. W analizie danych uwzględnienie trzech domen instytucji, wśród przypadków, które posłużyły za ilustrację przedsiębiorczości instytucjonalnej, pozwoliło dostrzec dwa różne wzorce. Firma II, która dokonywała replikacji swojego modelu biznesu na rynku zagranicznym ograniczenia instytucjonalne postrzegała jako zagrożenia. Stanowiły one jednak motywację do poszukania niestandardowych rozwiązań. Można stwierdzić, że pole do rozwoju nowych pomysłów wyznaczały ograniczenia, które ujawniało porównanie funkcji instytucji dojrzałego rynku i rynku wyłaniającego się. W tym sensie tradycyjny model instytucji stanowił dla menedżerów „filtr poznawczy”. W pierwszej kolejności analizowano możliwości wykorzystania instytucji w filarze regulatywnym, oraz w stosunkowo jawnym zakresie filaru kognitywnego. Zidentyfikowane ograniczenia pokonywano, szukając rozwiązań, w większym stopniu ukrytych dla inwestora zagranicznego, aspektach uwarunkowanych historycznie i kulturowo. $\mathrm{Na}$ tej podstawie dokonywano adaptacji modelu biznesu.

Inny wzorzec zidentyfikowano w przypadku Firmy I, która w obliczu odczuwanej złożoności otoczenia stanowiła ilustrację najbardziej otwartego podejścia do instytucji. Firma I ograniczenia instytucjonalne traktowała jako szanse wyznaczające kierunki na ścieżce swojego rozwoju. Wyróżniające dla tego przypadku było to, iż jako priorytet traktowano społeczną legitymizację prowadzonych działań. W tym przypadku, w sposób najbardziej twórczy, łączone były wszystkie filary instytucji Przykładowo, udział w roli eksperta w rządowym programie szkoleń, poza samą edukacją, propagował stosowane przez Firmę I rozwiazania techniczne, podnosił społeczną legitymizację działań jako inwestora zagranicznego, przy okazji spełniał funkcję reklamy. Fakt, iż szkolenia odbywały się w trakcie realizacji projektu, mobilizował także inwestora do większej współpracy i zaangażowania. Działalność ta nie była nastawiona na zysk, ale pozwoliła na nawiązanie kolejnych relacji, które z kolei otwierały przed Firmą I kolejne szanse. Ogólnie rzecz ujmując: brak infrastruktury rynku w sferze instytucji formalnych $\mathrm{z}$ powodzeniem zastępowano instytucjami o charakterze nieformalnym.

Przedstawione przykłady sugerują, że przedsiębiorstwa, które potrafią godzić swoje strategie z instytucjonalnym otoczeniem mają szansę na poprawę wyników. $\mathrm{Na}$ koniec należy zaznaczyć, iż transformacja i zmiany instytucji sprawią, iż wcześniejsze dostosowanie może stać się obciążeniem w nowych okolicznościach. Dynamiczne otoczenie wymaga ciągłej atencji w zakresie reguł gry, które wpływają na ocenę podejmowanych decyzji strategicznych. Firmy, które odniosły sukces, mają skłonność do stosowania dotychczasowych wzorców działania, gdyż nie pojawia się w otoczeniu presja podejmowania ryzyka nowych sposobów konfiguracji zasobów. Pojawia się więc skłonność do pasywnego powielania wzorców w sytuacji, gdy sam sukces odnoszony w ,grze” zmienia „grę”. W tej sytuacji nieustępliwość w stosowaniu starej gry przekształca sukces w błąd. W tym świetle rozwój w warunkach rynków wyłaniających się, kompetencji w zakresie przedsiębiorczości instytucjonalnej, we współczesnej 
rzeczywistości, stanowi cenną lekcję także dla przedsiębiorstw stosujących tradycyjne strategie budowy przewagi konkurencyjnej.

\section{Przypisy}

1 Ułomność rynku powstaje, gdy ekonomicznie uzasadniona transakcja (korzystna dla sprzedającego i kupującego) nie może być zrealizowana $\mathrm{z}$ powodu pośredniego kosztu tej transakcji, który przewyższa korzyści netto (Williamson, 1975; Williamson, 1998).

2 Servicio Nacional de Aprendizaje - SENA instytucja podległa Ministerstwu Pracy i Ubezpieczeń Społecznych. Jej celem jest inwestowanie w społeczny i techniczny rozwój zasobów ludzkich w Kolumbii, http://www.sena.edu.co.

\section{Bibliografia}

Baden-Fuller, C. i Winter, S.G. (2005). Replicating Organizational Knowledge: Principles or Templates. Papers on Economic and Evolution 2005-2015. Max Planck Institute of Economics, Evolutionary Economics Group, 1-40.

Berger, P. i Luckmann, T. (1967). The Social Construction of Reality: A Treatise on the Sociology of Knowledge. London: Allen Lane.

Caves, R.E. (1996). Multinational Enterprise and Economic Analysis, edition 2007. Cambridge, UK Cambridge University Press, doi.org/10.1017/ CBO9780511619113.

De Wit, B. i Meyer, R. (2005). Strategy Synthesis. Resolving Strategy Paradoxes to Create Competitive Advantage, text and readings ( $2^{\text {nd }}$ ed.). London Thomson Learning.

Christensen C.M., Johnson M.W. i Rigby D.K. (2002). Foundations for growth. How to identify and built disruptive and new business. Sloan Management Review, 43, 22-31.

DiMaggio, P. (1988). Interest and Agency in Institutional Theory. W: L.G. Zucker (red.), Institutional Patterns and Organizations: Culture and Environment (s. 3-21). Cambridge, Ma: Ballinger.

DiMaggio, P.J. i Powell, W.W. (1983). The Iron Cage Revisited: Institutional Isomorphism and Collective Rationality in Organizational Fields. American Sociological Review, 48(2), 147-160, doi: $10.2307 / 2095101$

Dunning, J. (1988). The Eclectic Paradigm of International Production - An Update and Some Possible Extensions. Journal of International Business Studies, 19, 1-31

Dul, J., Hak, T., Goertz, G. i Voss, C. (2010). Necessary Condition Hypotheses in Operations Management. International Journal of Operations and Production Management, 30(11), 1170-1190, doi. org/10.1108/01443571011087378
Dyduch, W. (2013). Twórcza strategia organizacji. Katowice: Wydawnictwo Uniwersytetu Ekonomicznego w Katowicach.

Eirksson, J., Johanson, J., Majkgård, A. i Sharma, D.D. (1997). Experiential Knowledge and Costs in the Internationalization Process. Journal of International Business Studies, 28(2), 337-360.

Eisenhardt, K.M. i Graebner, M.E. (2007). Theory Building From Cases: Opportunities and Challenges. Academy of Management Journal, 50(1), 25-32, doi:10.5465/AMJ.2007.24160888.

Forsgren, M., Holm, U. i Johanson, J. (2005). Managing the Embedded Multinational: A Busines Network View. Cheltenham, Northampton, Massachusetts: Edward Elgar.

Goldstein, A. (2007). Multinational Companies From Emerging Economies. New York: Palgrave Macmillan.

Hymer, S. (1976). The International Operations of National Firms: A Study of Direct Foreign Investment. Cambridge: MIT Press.

Johnson, S., LaPorta, R., Lopez-de-Silanes, F. i Shleifer, A. (2000). Tunnelling. American Economic Review, 90(2), 22-27.

Johanson, J. i Vahlne, J.-E. (1977). The Internationalization Process of the Firm: A Model of Knowledge Development and Foreign Market Commitment. Journal of International Business Studies, 8(1), 23-32.

Hardgrave T. i Van de Ven A. (2006). A Collective Action Model of Institutional Innovation. The Academy of Management Review, 31(4), 864-888, doi: 10.5465/AMR.2006.22527458

Heiko, G, Worch, H. i Bernhard T. (2012). Absorptive Capability, Learning Process and Combinative Capabilities as Determinants of Strategic Innovation. European Management Journal, 30, 57-73.

Khanna, T. i Palepu, K.G. (1997). Why Focused Strategies May Be Wrong for Emerging Markets? Harvard Business Review, Jul./Aug., 41-51.

Khanna, T. i Palepu, K.G. (2006). Emerging Gigants. Building World-Class Companies in Developing Countries. Harvard Business Review, 84(10), 60-70.

Khanna, T. i Palepu, K.G. (2010). Winning in Emerging Markets: A Road Map for Strategy and Execution. Boston, Massachusetts: Harvard Business Press.

Khanna, T., Palepu, K.G. i Sinha, J. (2005). Strategies That Fit Emerging Markets. Harvard Business Review, 83, 63-76.

Knight, F. (1929). Freedom as Fact and Criterion. International Journal of Ethics, 39(2), 129-147.

Kostova, T. i Zaheer, S. (1999). Organizational Legitimacy Under Conditions of Complexity: the Case of the Multinational Enterprise. Aca- 
demy of Management Review, 24(1), 64-81, doi: $10.2307 / 259037$

Lall, S. (1983). The New Multinationals; The Spread of Third World Enterprises. Chichester: Wiley.

Lecraw, D.J. (1977). Direct Investment by Firms from Less Developed Countries. Oxford Economic Papers, 29(3), 442-457.

Lecraw, D.J. (1993). Outward Direct Investment by Indonesian Firms: Motivation and Effects. Journal of International Business Studies, 24(3), 589-600, doi:10.1057/palgrave.jibs.8490247.

Li, Y. i Peng, W. (2008). Developing Theory from Strategic Management Research in China. Asia Pacific Journal of Management, 25.

Mathews, J.A. (2006). Dragon Multinationals: New Players in $21^{\text {st }}$ Century Globalization. Asia Pacific Journal of Management, 23(1), 5-27, doi org/10.1007/s10490-006-6113-0.

Meyer, K. (2004). Perspectives on Multinational Enterprises in Emerging Economies. Journal of International Business Studies, 35(4), 259-276, doi:10.1057/palgrave.jibs.8400084.

Meyer, J.W. i Rowan, B. (1977). Institutionalized Organizations: Formal Structure As Myth and Ceremony. American Journal of Sociology, 83, 340363, doi: $10.1086 / 226550$.

Meyer, J.W. i Scott, W.R. (red.). (1983). Organizational Environments: Ritual and Rationality. Beverly Hills, CA: Sage Publications, Inc.

North, D.C. (1990). Institutions, institutional change and economic performance. Cambridge: Harvard University Press, MA, doi: 10.1017/ CBO9780511808678.

North, D.C. (2005). Understanding the Process of Economic Change. Princeton, NJ: Princeton University Press.

Oliver, C. (1991). Strategic Responses to Institutional Processes. Academy of Management Review, 16(1), 145-179, http://dx.doi.org/10.5465/ AMR.1991.4279002.

Peng, M.W. i Luo, Y. (2000). Managerial Ties and Firm Performance in a Transition Economy: The Nature of a Micro-Macro Link. Academy of Management Journal, 43(3): 486-501, doi $10.2307 / 1556406$

Pitt, M. i Clarke, K. (1999). Competing on Competence: A Knowledge Perspective on the Management of Strategic Innovation. Technology and Analysis and Strategic Management, 11, 301-316.

Prahalad, C.K., Krishnan, M.S. i Donker, A. (2004) Building Blocks of Global Competitiveness. Optimize, September, 30-36.

Prahalad, C.K. i Lieberthal, K. (2003). The End of Corporate Imperializm. Harvard Business Review, 81(8), 109-117.

Raffaelli, R. i Glynn, M.A. (2015). Institutional Innovation: Novel, Useful, and Legitimate. W: Ch.E. Shalley, M.A. Hitt i J. Zhou (red.), Oxford Handbook of Creativity, and Entrepreneurship: Multilevel Linkages. Oxford University Press.

Scott, W.R. (2001). Institutions and Organizations. Thousands Oak, California: Sage.

Strauss, A. i Corbin, J.M. (1998). Basics of Qualitative Research: Techniques and Procedures for Developing Grounded Theory. London: Sage Publications

Williamson, O.E. (1975). Markets and Hierarchies: Analysis and Antitrust Implications. New York: Free Press.

Williamson, O.E. (1991). Comparative Economic Organization: The Analysis of Discrete Structura Alternatives. Administrative Science Quarterly, 36, 269-296, doi: 10.2307/2393356.

Williamson, O.E. (1998). Ekonomiczne instytucje kapitalizmu. Warszawa: Wydawnictwo Naukowe PWN

Winter, S.G. i Szulanski G. (2001). Replication As Strategy. Organization Science, 12(6), 730-743, doi: 10.1287//orsc.12.6.730.10084

Yip, G.S. (1996). Strategia globalna. Światowa przewaga konkurencyjna. Warszawa: PWE.

Yin R.K. (1981). The Case Study Crisis: Some Answers. Administrative Science Quarterly, 26, 58-65, doi: 10.2307/2392599.

Zimmerman, M. i Zeitz, G. (2002). Beyond Survival: Achieving New Venture Growth by Building Legitimacy. Academy of Management Review, 27(3), 414-431, doi: 10.5465/AMR.2002.7389921. 